\title{
Biopsy of Testis
}

National Cancer Institute

\section{Source}

National Cancer Institute. Biopsy of Testis. NCI Thesaurus. Code C51894.

Removal of testicular tissue for microscopic examination. 